\title{
ЗБИРАННЯ ТА ПОДАННЯ ДОКАЗІВ ЯК СКЛАДНИК ФУНКЦІї ЗАХИСТУ У КРИМІНАЛЬНОМУ ПРОВАДЖЕННІ
}

Сільницький І. В.

Cтаття присвячена дослідженню діяльності сторони захисту у кримінальному провадженні, пов'язаній із збиранням та поданням доказів в умовах чинного Кримінального процесуального законодавства. Приділено увагу історичному аспекту становлення та розвитку інституту подання доказів у кримінальному судочинстві. Здійснюється аналіз відповідних положень КПК України, Закону «Про адвокатуру та адвокатську діяльність», що регламентують права та обов'язки захисника, які на сьогоднішній день значно розширені, та забезпечують рівність прав сторін кримінального провадження щодо збирання і подання дока зів. Зазначено, що це сприяє належній реалізації права громадян на професійну правову допомогу.

Ключові слова: кримінальне провадження, функція захисту, адвокат, правова допомога, докази, рівність сторін кримінального судочинства.

Статья посвящена исследованию деятельности стороны защиты в уголовном производстве, связанной со сбором и предоставлением доказательств в условиях действующего Уголовного процессуального законодательства. Уделено внимание историческому аспекту становления и развития института предоставления доказательств в уголовном судопроизводстве. Произведен анализ соответствующих положений УПк Украины, Закона Украины "Об адвокатуре и адвокатской деятельности", которые регламентируют права и обязанности защитника, которые на сегодняшний день значительно расширены, и обеспечивают равенство прав сторон уголовного производства по сбору и предоставлению доказательств. Отмечено, что это способствует надлежащей реализации права граждан на профессиональную правовую помощь.

Ключевые слова: уголовное производство, функция защиты, адвокат, правовая помощь, доказательства, равенство сторон уголовного судопроизводства.

The article is devoted to the investigation of the activities of the party of defense in criminal proceedings related to the collection and presentation of evidence under the current Criminal Procedure Code. Attention is paid to the historical aspect of the establishment and development of the Criminal Justice Competitiveness Institute regarding the equal rights of the parties to present evidence.

It is noted that the current Criminal Procedure Code of Ukraine introduced a number of changes aimed at further affirming the parties' competitiveness and freedom to collect and present evidence. The relevant provisions of the CPC of Ukraine, the Law on Advocacy and Attorneys' Law, regulating the rights and duties of the defense lawyer, who is a participant in the defense function, is a participant in the collection and presentation of evidence. He is authorized to collect information about facts that can be used as evidence, in accordance with the procedure established by law, to request, receive and remove things, documents, their copies, to familiarize with them and to interview persons with their consent, to obtain written conclusions of specialists, experts on issues that need special knowledge. Attention is drawn to the fact that the CCP has significantly expanded the rights of the defense party to collect evidence, namely to initiate investigative (investigative) actions, unspoken investigative (investigative) actions and other procedural actions capable of providing the court with proper and admissible evidence. Novelties in the activities of defense counsel in criminal proceedings also include obtaining a defense attorney on the basis of the decision of the investigating judge or court temporary access to things and documents and carrying out, if necessary, their withdrawal, the involvement of a defense expert to conduct an examination. The defense counsel's right to have a confidential date with the suspect without the investigator's permission has been extended, and the defense counsel's replacement or replacement should only take place in the presence of the defense lawyer after providing the opportunity for confidential communication.

Attention is drawn to the fact that without the defense counsel, the defense party's task of collecting and presenting evidence is extremely difficult or impossible. On the whole, this issue is an integral part of the defense counsel's involvement in the criminal process, which is important today and contributes to the proper exercise of the right of citizens to professional legal assistance.

Key words: criminal proceedings, defense function, lawyer, legal assistance, evidence, equality of parties to criminal proceedings.

Постановка проблеми та її актуальність. Одним із важливих напрямів кримінальної процесуальної політики української держави $\epsilon$ формування такого кримінального процесуального законодавства, за якого б не тільки створювалися умови ефективної діяльності для правоохоронних органів, а й максимально реалізовувалися конституційні засади, які гарантують захист особистості, її права і свободи, інтереси суспільства і держави. Відповідно до ст. 7 КПК зміст та форма кримінального провадження повинні відповідати загальним засадам кримінального провадження [2, ст. 7]. Засади кримінально-процесуального права - це закріплені в правових нормах вихідні положення, що відбивають панівні в державі політичні та правові ідеї і визначають сутність організації і діяльності компетентних державних органів щодо досудового розслідування і судового розгляду кримінальних справ. Важливе місце серед засад кримінального провадження займає змагальність сторін та свобода в поданні ними суду своїх доказів і у доведенні перед судом їх переконливості. Невипадково ст. 22 Кримінального процесуального кодексу України визначає рівність прав сторін кримінального провадження на збирання та подання до суду речей, документів та інших доказів [2, ч. 2 ст. 22]. Тобто захисник, здійснюючи функцію захисту, $\epsilon$ учасником збирання і подання доказів.

Аналіз останніх досліджень і публікацій. Проблеми збирання i подання доказів, участі захисника 
В кримінальному провадженні розглядали у своїх працях відомі українські вчені, а саме, Ю.П. Аленін, Т.В. Варфоломєєва, В.М. Гмирко, В.Г. Гончаренко, Ю.М. Грошевий, В.Г. Лукашевич, Л.М. Лобойко, В.Т. Нор, В.О. Попелюшко, Л.Д. Удалова, В.І. Фаринник, М.Є. Шумило, О.Г. Яновська та інші. Разом з тим увага проблемам збирання і подання доказів стороною захисту розглядалася недостатньо. Таке положення не відповідає сьогоденним потребам науки та практики, оскільки існує нагальна необхідність у зміцненні основоположних засад кримінального процесу, забезпеченні належної реалізації рівних прав та можливостей сторін кримінального провадження.

Мета статті - дослідити діяльність сторони захисту у кримінальному провадженні, пов'язану із збиранням та поданням доказів в умовах чинного Кримінального процесуального законодавства.

Виклад основного матеріалу. Згідно з ч. 1 ст. 84 КПК доказами в кримінальному провадженні $\epsilon$ фактичні дані, отримані у передбаченому КПК порядку, на підставі яких слідчий, прокурор, слідчий суддя і суд встановлюють наявність чи відсутність фактів та обставин, що мають значення для кримінального провадження та підлягають доказуванню [2, ст. 84]. Поняття доказу включає в себе також і джерела доказів, що являють собою певні носії доказової інформації, тобто відомості про факти, які підлягають доказуванню під час здійснення кримінального провадження. Носіями такої інформації можуть бути люди (свідки, потерпілі, підозрювані, обвинувачені та інші) і предмети матеріального світу (предмети, які були знаряддям злочину, зберегли на собі сліди злочину, викрадені цінності тощо). Види джерел доказів суворо обмежені законом, і перелік їх не може бути свавільно розширений. Вони перелічені у ч. 2 ст. 84 КПК іє вичерпними. Це: показання, висновки експерта, речові докази, документи [2, ст. 84].

Проблема збирання і подання доказів стороною захисту у кримінальному провадженні має історичне минуле. Історія становлення та розвитку інституту подання доказів тісно пов'язана з іншими дискусійними питаннями кримінального процесуального судочинства: історичними формами кримінального процесу, засадою змагальності тощо. Аналізуючи історичний аспект становлення інституту збирання і подання доказів, одним з основних джерел кримінального процесуального права слід визнати Статут кримінального судочинства 1864 року, який був прийнятий у межах судової реформи 1864 року. У цьому документі чи не вперше було викладено основні положення кримінального судочинства, які мали суттєвий вплив на подальший розвиток процесуального законодавства. На думку професора В.М. Тертишника, у цьому досить таки змістовному законодавчому акті були реалізовані фундаментальні ідеї, які роблять його найпрогресивнішим процесуальним законом того часу, а нерідко слугують джерелом творчих пошуків вчених [5, с. 70]. Зокрема, Статут кримінального судочинства передбачав можливість проведення і детально регламентував низки слідчих дій: огляд і освідування (ст.ст. 315-356), обшуку і виїмки в будинках (ст.ст. 357-370), допиту обвинуваченого (ст.ст. 398-414), допиту свідка і очної ставки (ст.ст. 441-453). Крім того, детально регламентувалася процедура збирання і збереження речових доказів (ст.ст. 371-376). Однак спеціальної норми, яка регулювала б процедуру та суб'єктів подання доказів, Статут кримінального судочинства не містив. Разом з тим у деяких випадках норми Статуту торкалися окремих аспектів подання доказів учасниками процесу під час регламентації інших питань кримінального судочинства, зокрема, обов'язку доказування у кримінальних справах статусу суб'єктів кримінального процесу, усності і змагальності судочинства тощо [6, с. 325].

Такий аспект, як змагальність судочинства, набув певного поширення у Кримінально-процесуальному кодексі України 1960 року. Якщо проаналізувати статтю 16-1 «Змагальність і диспозитивність», то з'ясуємо, що розгляд справ у судах відбувався на засадах змагальності. При цьому функції обвинувачення, захисту і вирішення справи не могли покладатися на один і той же орган чи на одну і ту ж особу. Захист підсудного здійснював сам підсудний, його захисник або законний представник [3, ст. 48]. Відповідно до статті 48 КПК 1960 року захисник мав право тільки збирати відомості про факти, що можуть використовуватися як докази в справі, в тому числі запитувати і одержувати документи чи їх копії від громадян та юридичних осіб, знайомитися на підприємствах, в установах, організаціях, об'єднаннях громадян з необхідними документами, крім тих, таємниця яких охороняється законом, одержувати письмові висновки фахівців з питань, що вимагають спеціальних знань, опитувати громадян [3, ст. 48].

Сьогодні чинний Кримінальний процесуальний кодекс України суттєво змінив порядок здійснення кримінального судочинства, запровадилися низки змін, спрямованих на подальше утвердження засади змагальності сторін та свободи в збиранні та поданні ними доказів. Не стала винятком і діяльність захисника, який, здійснюючи функцію захисту, є учасником збирання і подання доказів. При цьому ключовою фігурою з боку захисту $є$ адвокат, який згідно зі ст. 20 Закону України «Про адвокатуру та адвокатську діяльність» здійснює захист прав, свобод і законних інтересів підозрюваного, обвинуваченого, підсудного, засудженого, виправданого та інших осіб [4, п. 3 ст. 19]. Відповідно до ст. 20 зазначеного Закону він уповноважений збирати відомості про факти, що можуть бути використані як докази, в установленому законом порядку запитувати, отримувати і вилучати речі, документи, їх копії, ознайомлюватися з ними та опитувати осіб за їх згодою [4, п. 7 ст. 20]. Він також має право одержувати письмові висновки фахівців, експертів з питань, що потребують спеціальних знань [4, п. 10 ст. 20].

Питання збирання доказів у кримінальному провадженні $\epsilon$ настільки важливим, що законодавець відвів для нього окрему статтю - ст. 93 КПК України, в якій окремо визначив шляхи збирання доказів стороною захисту [2, ст. 93]. Згідно з частиною 3 цієї статті значно розширені права сторони захисту щодо збирання доказів, а саме щодо ініціювання проведення слідчих (розшукових) та негласних слідчих (розшукових) та інших процесуальних дій, а також щодо здійснення дій, які здатні забезпечитиподаннясудуналежнихідопустимихдоказів.

До останніх дій, які $є$ новими для діяльності захисника в кримінальному процесу України, слід віднести отримання захисником на підставі ухвали слідчого судді чи суду тимчасового доступу до речей i документів та проведення за необхідності їх вилучення, залучення стороною захисту експерта для проведення 
експертизи. Також чинним КПК розширилися права захисника на право мати конфіденційне побачення з підозрюваним без дозволу слідчого, а відмова від захисника або його заміна повинна відбуватися винятково в присутності захисника після надання можливості конфіденційного спілкування [2, ч. 2 ст. 54]. Сприяє захисту і розширення змагальності під час досудового розслідування кримінальних правопорушень відповідно до чинного кримінального процесуального законодавства України, оскільки більшість заходів забезпечення кримінального провадження обираються за рішенням слідчого судді із застосуванням змагальної процедури судового розгляду клопотання сторони кримінального провадження. Участь захисника в цьому судовому розгляді забезпечує захист законних інтересів підозрюваного. Відповідно до положень ч. 1 ст. 22 КПК України кримінальне провадження здійснюється на основі змагальності, що передбачає самостійне обстоювання стороною захисту їхніх правових позицій, прав, свобод і законних інтересів засобами, передбаченими КПК, а також мають рівні права на збирання та подання до суду речей, документів та інших доказів.

Висновки. Вказане питання $\epsilon$ складником проблематики участі захисника у кримінальному процесі, що сьогодні $\epsilon$ надважливою $з$ погляду належної реалізації права громадян на професійну правову допомогу, а також додержання гарантій адвокатської діяльності. Без участі захисника виконання стороною захисту завдання щодо збирання і подання доказів $\epsilon$ вкрай складним або, навіть, неможливим. При цьому слід враховувати, що на цей час відсутні будь-які рекомендації чи методичні вказівки щодо збирання і подання доказів стороною захисту у кримінальному провадженні. Таке положення не відповідає сьогоденним потребам науки та практики, оскільки існує нагальна необхідність реалізації права громадян на професійну правову допомогу. Отже, сьогодні комплексна розробка теоретичних, нормативно-правових та організаційних основ збирання і подання доказів стороною захисту у кримінальному провадженні $\epsilon$ актуальною та своєчасною.

\section{Література}

1. Конституція України [Електронний ресурс] : закон України від 28 червня 1996 р. № 254к/96-ВР : за станом на 21.02.2014 p. URL: http://zakon1.rada.gov.ua. (дата звернення: 13.04.2019).

2. Кримінальний процесуальний кодекс України [Електронний ресурс] : закон України від 13.04.2012 р. № 4651-VI : за станом на 16.03.2018 p. URL: http://zakon3.rada.gov.ua. (дата звернення: 16.03.2019).

3. Кримінально-процесуальний кодекс України [Електронний ресурс] : закон України від 28.12.1960 p. № 1001-05 : втратив чинність 19.11.2012 р. № 4651-17. URL: http://zakon3.rada.gov.ua. (дата звернення: 15.01.2020).

4. Про адвокатуру та адвокатську діяльність [Електронний ресурс] : закон України від 05.07.2012 р. № 5076-VI : за станом на 21.12.2017 p. URL: http: / /zakon5.rada.gov.ua. (дата звернення: 27.03.2019).

5. Тертишник В.М. Кримінально-процесуальне право України : підручник. Київ : АСК, 2003. 392 с.

6. Крушинський С.А. Подання доказів у кримінальних справах за Статутом кримінального судочинства 1864 року. Університетські наукові записки. 2011. № 3 (39). C. 324-329.

Сільницький I. В., аспірант заочної форми навчання докторантури та аспірантури Одеського державного університету внутрішніх справ 